\section{COMPOSITAE}

Solidago spathulata DC.-Rare in opening of an aspen forest north of Fond-du-Lac River. Thiis extends the known northern range in Saskatchewan. Stony Rapids 591.

Aster laevis L.-Roadside collection. This plant was reported at McMurnay, Chipewyan and L. Mamawi by Raup. This collection extends the range into nonthern Saskatchewan. Sitony Rapids 574.

Aster ciliolatus Lindl.-Rare in moist areas of a mixed black spruce and jack pine forest. Stony Rapids 570.

Achillea sibirica Ledeb.-Rare on a rock outcrop. This collection is a northern extension of the known range in Saskatchewan. Newnham L. 613.

Achillea lanulosa Nutt.-Roadside collection. Stony Rapids 558.

Matricaria matricariodes (Less.) Ponter-Common on abandoned campsites. Stony Rapids 564.

Petasites palmatus (Ait.) A. Gray -Infrequent on moist areas. Oblate L. 481, McKeever L. 507.

Petasites vitifolius Greene-Common in townsite and along road ditches. Stony Rapidis 578.
Petasites sagittatus (Pursh) A Gray-Rare in moist areas of a birch forest. McKeever L. 497.

Senecio pauperculus Michx. var. flavovirens (Rydb.) Boivin - Infrequent in an aspen forest north of the Fond-du-Lac River. Stony Rapids 589.

Taraxacum dumetorum GreeneRare on a rocky island. McKeever L. 517 .

Taraxacum officinale Weber Common in the townsite. Stony Rapids 553.

Hieracium scabriusculum, Schwein. - Infrequent on rock outcrops and in aspen forests. Stony Rapids 590, Newnham L. 614.

\section{LITERATURE CITED}

Alcock, F. J. 1936. The Geology of the Athabaska Region. Geol. Surv. Canada. Memoir 196. 1-41.

Bnietung, A. J. 1957. Annotated catalogue of the vascular flona of Saskatchewan. Amer. Mid1. Nat. 58:1-72.

Fraser, W. P., and R. C. Russe11. 1954. An annotated list of the plants of Saskatchewan. Univensity of Saskatchewan, Saskatoon, Sasklatchewan. 1-47.

Preble, E. A. 1908. A biological investigation of the Athabaska-MacKenzie region. U.S. Dept of Agric. No, 27. 1-574.

Raup, H. M. 1936. Phytogeographic studies in the Athabaska-Great Slave Lake region. Jour. Arn. Arb. $17: 180-315$ pp.

Tyrrell, J. W., 1908. Across the sub-arctics of Canada. William Briggs, Toronto. 1-280.

\title{
Large-flowered Hemp Nettle
}

(Galeopsis speciosa)

\section{by E. H. Moss, Edmonton}

Many readers of the Blue Jay are doubtless acquainted with the Common Hemp Nettle, Galeopsis tetrahit, an introduced weed of waste places, roadsides and fields. Perhaps few know that it is of hybrid origin, the parent species being $G$. pubescens and $G$. speciosa. This was shown some thirty years ago by Muntzing in Sweden. By crossing the two parent species Muntzing obtained a plant which, though highly sterile, was successfully back-crossed to G. pubescens. The latter cross gave a fertile plant which was indistinguishable from $G$. tetrahit, a species long known in nature.

The main purpose of this rote is to report the occurrence of Galeopsis speciosa, the Large-flowered Hemp Nettle, in Alberta. During the summer of 1960 specimens came to hand from two localities near Edmonton.
Dr. G. H. Turner submitted speciments collected near Fort Saskatchewan. From Mr. George Pegg came plants found near Heatherdown, some thirty miles northwest of Edmonton. The species is said to be prevalent at Heatherdown and to be spreading there. These collections appear to represent the first records of the species for Alberta, and possibly for Canada, apart from a collection made at Millet ( 30 miles south of Edmonton) in 1928. The latter collection, reported to the writer by Dr. C. Frankton, is in the herbarium of the Department of Agriculture, Ottawa. Dr. A. E. Porsild has informed Dr. Turner that there are no Canadian collections of the species in the National Herbarium, Ottawa.

The Large-flowered Hemp Nettle may be expected in ather parts of western Canada. Moreover, it may 
prove to be an aggressive weed in certain regions. 'The plant is at once distinguishable from the common hemp nettle by its much larger and markedly yellow flowers. Its corolla is an inch or more long, pale yellow with a violet spot on the lower lip, the tube much longer than the calyx.
In contrast, the corolla of the Common Hemp is less than an inch long, pink or white or variegated, often with two yellow spots, and the tube rarely exceeds the calyx. The stem of the Large-flowered Hemp Nettle is more uniformly bristly-hairy than is that of the other species.

\section{Large Stone Contest}

by W. O. Kupsch, University of Saskatchewan, Saskatoon

Field stones, which are so abundant in the settled part of Saskatchewan, and which cause farmers much grief by their presence, are of interest because they were transported to their present site by flowing glacier ice, which covered most of the province until about 10,000 years ago. Geologists refer to giant rocks bigger than a house. The largest in Western Canada, and possibly in the world, is undoubtedly "Big Rock" near Okotoks, Alberta. This erratic, brought onto the plains by a glacier coming from the Rocky Mountains, measures $135 \times 60 \times 30$ feet and weighs over 18,000 tons!

Although nathing of such a tremendous size as "Big Rock" is known from Saskatchewan, the writer believes that a record is needed on large field stones in this province. It is, of course, difficult to define "large" in this respect, but any stone that can be moved by man power or ordinary farm machinery is not worth considering. For convenience, let it be arbitrarily established that the smallest dimension of a "large" stone should be at least the height of a man, or about 6 feet.

If you know of any "large" field stones within the boundaries of Saskatchewan, you are invited to take part in a contest to determine where the largest erratic is located. All you have to do is to provide me with the following:

1. Location of the stone as to section, township, range and the distance and direction to the nearest town. Give me the name of the rock, if a local name is commonly applied to it.

2. The dimensions of the stone measured with a tape. This will, of necessity, be only a rough measure because stones are not square boxes. Try, however, to get length, width, and height, as fairly as possible.

3. A ahip of the rock, knocked off with a hammer, about the size of a base ball.

The parcel containing the chip and the information can be sent collect to my address, so no costs are involved for you. The reporters of the three largest stones will each receive a copy of the Glacial Map of Canada, which tells you of the changes made by glaciers to the face of our country, as a prize. The contest will be open until December 31, 1961, because most of us are not likely to get out into the field to look for big erratics until summer and fall. After evaluation of ail entries, I will give you a report on the distribution of large erratics in Saskatchewan in a future issue (1962) of the Blue Jay.

\section{SNHS SPECIAL PUBLICATIONS}

\section{A Guide to Saskatchewan} Mammals-by W. H. Beck. Special Publicatinns Nn. 1. Saskatchewan Natural History Society, Regina, 1958. 50 Cents.

The Birds of the Saskatchewan River, Carlton to Cumberland-by C. Stuart Houston and Maurice G. Street. Special Publications No. 2, Saskatchewan Natural History Society, Regina. 1959. \$1.50.

Order Special Publications from Dr. Stuart Houston, 2401 Hanover Ave., Saskatoon, Sask. 